\title{
EVALUATION OF SELF-REGULATED LEARNING ON PROBLEM-SOLVING SKILLS IN ONLINE BASIC PHYSICS LEARNING DURING THE COVID-19 PANDEMIC
}

\author{
Ahmad Abtokhi $^{1,2}$ iD, Budi Jatmiko ${ }^{1}$, Wasis Wasis ${ }^{1}$ (DD \\ ${ }^{1}$ Universitas Negeri Surabaya (Indonesia) \\ ${ }^{2}$ Universitas Islam Negeri Maulana Malik Ibrahim (Indonesia) \\ abtokbi@fis.uin-malang.ac.id,budijatmiko@unesa.ac.id,wasis@unesa.ac.id
}

Received January 2021

Accepted July 2021

\section{Abstract}

The problems of learning physics have experienced increasingly complex obstacles amid the demands of online learning due to the COVID-19 pandemic. The purpose of this study is to explain the basic physics learning process through an online system during a pandemic, by evaluating the Self-Regulated Learning (SRL) approach to Problem-Solving Skills (PSS). Data were collected through distributing questionnaires, interviews and documentation studies, then analyzed. This study shows that the applied SRL has been implemented well but has not been optimal in improving PSS in online Basic Physics learning. The unpreparedness of technological devices and the competence of educators and students become obstacles that result in difficulties in solving physics problems so that the expected results are not following the expected learning targets. Also, this study shows the difficulty of learning physics online during the pandemic. Thus, a responsive physics learning model is needed with conditions that allow the delivery of physics material to be well understood, even though it is delivered through digital media. This is a demand that needs the attention of all parties so that the achievement of online learning targets remains optimal and effective in increasing the problem-solving skills of students during the COVID-19 pandemic.

Keywords - COVID-19, Evaluation, Physics learning, Problem-solving skill, Self-regulated learning.

\section{To cite this article:}

Abtokhi, A., Jatmiko, B., \& Wasis, W. (2021). Evaluation of self-regulated learning on problem-solving skills in online basic physics learning during the COVID-19 pandemic. Journal of Technology and Science Education, 11(2), 541-555. https://doi.org/10.3926/jotse.1205

\section{Introduction}

Physics learning which is identical to meeting in person directly cannot be taught effectively through online media. The number of physics problems that need to be solved directly or offline is an obstacle that results in increasing student difficulty in solving physics problems. This can be seen from the weakness of the student's Problem-Solving Skill (PSS) in online learning during the pandemic. In the physics learning process, it is necessary to visualize the material for problem-solving (Kozhevnikov, Motes \& Hegarty, 2007). Various problems arise due to the implementation of online learning for all levels of 
education during the pandemic with various challenges that accompany it (Almaiah, Al-Khasawneh \& Althunibat, 2020; Chick, Clifton, Peace, Propper, Hale, Alseidi et al., 2020; Daniel, 2020). This includes learning physics which has experienced various obstacles that are not easily taught online. Thus, we need some technique for the optimization of online physics learning, so that it does not increase the difficulty in problem-solving.

Studies so far tended to see an increase in students PSS from three perspectives. First, problem-solving concept and method with various perspective (Anderson, 1993; Norman, 1988; Retnowati, Fathoni \& Chen, 2018; Singh, 2009; Sweller, 1988; Van Merriënboer, 2013). The importance of critical thinking in problem-solving (Rodzalan \& Saat, 2015; Snyder \& Snyder, 2008). Second, PSS are applied in certain subjects (Jacobse \& Harskamp, 2012; Karatas \& Baki, 2013; Kim \& Hannafin, 2011; Krawec, 2014; Schoenfeld, 2016; Tambychik \& Meerah, 2010). Even problem-solving can be done with an approach of playing game (Barzilai \& Blau, 2014; Learning, 2001). Sanches and Olivares (2011) reveal that learning activity based on Mobile Serious Games can give a contribution to increase high-level learning PSS (Sánchez \& Olivares, 2011). Third, problem-solving has also been used in solving physics problems (Carleo \& Troyer, 2017; De Cock, 2012; Landau, Páez-Mejía \& Bordeianu, 2015; Mestre, Docktor, Strand \& Ross, 2011; Walsh, Howard \& Bowe, 2007), where the approach of conceptual problem-solving becomes an alternative for solving various physics problems (Mestre et al., 2011). Therefore, this study begins from these three trends by evaluating the Self-Regulated Learning (SRL) against the PSS in online physics learning that has not received much attention in the previous studies. The study conducted by (English \& Kitsantas, 2013) observed the use of SRL in problem-based learning.

Three questions can be asked as a reference in the discussion of this study. (1) How to form SRL which is easy to understand and practice by students in the physics learning process online? (2) What is the dominant indicator in the student PSS process in solving physics problems? (3) How SRL has not been able to influence student PSS as applied to online physics learning? Apart from being the answer to the problems discussed, these three questions also test the hypotheses proposed in this study.

Based on these problems, the hypothesis of this study can be illustrated that physics learning, which is identical to touchable material, still leaves unfinished problems until now. Various approaches have been taken, but they have not had a significant impact. The problems that arise are still dominated by difficulties in understanding learning as a result of the lack of intensity of meetings directly in line with the outbreak of the COVID-19 pandemic. In this condition, almost all educational processes are run online which are followed by various problems. The unpreparedness of educators and students is one of the main obstacles in learning physics online during the pandemic. Also, unequal access to technology is the reason for ineffective learning, where technology is the main support that cannot be avoided.

\section{Literature Review}

\subsection{Self-Regulated Learning (SRL)}

Independent learning is a way of developing skills and reasoning, which is followed by the ability to organize actions and the learning process (Kuiper-Anne \& Pesut, 2016). The independent learning process is characterized by proactive actions taken by students for the continuity of their education by utilizing knowledge, determining strategies, adjusting existing impacts, increasing learning confidence, and making decisions (Schunk \& Zimmerman, 2012). As stated in the statement, Hadwin, Järvelä and Miller (2015) revealed that independent learning affects increasing interest and willingness in learning where students are active agents who can control their learning. In research conducted by Wong, Baars, de Koning and Paas (2021) demonstrated that students are more successful when they independently engage in behaviors that control their desire to learn such as planning what to learn and reviewing the subject matter. This is in line with the statement from Clark (2012), that learning independently increases motivation and academic results because students can adaptively understand the characteristics of learning in accordance with their abilities. This was later explained by Hadwin, Järvelä and Miller (2015) that the process of forming independent learning begins with observational learning (modeling), then imitating and forming thought patterns and strategies that reflect how it looks. 
The learning system is independently implemented to encourage students to experiment, have initiative, and combine all skills and abilities to complete the learning process successfully (Castro-Schez, Glez-Morcillo, Albusac \& Vallejo, 2021). According to Schunk and Zimmerman (2012) independent learning is influenced by three main factors, namely personal factors in the form of beliefs, actions, and biological experiences; behavior; and environmental influences (interactions). As explained above, Winne (2010) shows that independent learning has four important stages that support the formation of learning experiences, namely (a) developing students' minds in handling the selected task; (b) setting objectives for planning; (c) planning and problem-solving; (d) giving breaks to do a reflection on the work that has been done. This stage is based on five important indicators mentioned by Syaf, Kuryadinata and Widiasty (2017) includes (1) diagnosis of learning needs; (2) selection of learning strategies; (3) monitoring and learning management; (4) setting the learning targets and objectives; (5) evaluation of learning processes and outcomes. Furthermore, independent learning affects emotional understanding in using online learning platforms where patterns of independence reveal limited interactions which reduce sensitivity in assessing students' emotions (Zheng, Huang, Li, Lajoie, Chen \& Hmelo-Silver, 2020).

\subsection{Problem-Solving Skills (PSS)}

Problem-solving is a learning method used to provide context and motivation in solving a problem (Argaw, Haile, Ayalew \& Kuma, 2017). According to Chua, Tan and Liu (2016) the process of forming problem-solving in students is based on 4 important stages including problem-solving, problem analysis, discovery and reporting, and evaluation to find solutions. Han and Toh (2019) emphasized that problemsolving motivation has influenced the improvement of students' skills and criticism in exploring any information (Chua et al., 2016). Hu, Wu and $\mathrm{Gu}$ (2017) found that many educational staff used problemsolving methods as solutions to overcome difficulties in science learning. problem-solving in science provides solutions for solving everyday problems where becomes the basis for determining actions and next steps (Laurens, Batlolona, Batlolona \& Leasa, 2018). This is in line with the statement of Sukariasih, Tahang, Nursalam and Fayanto (2020) which emphasizes that problem-solving in physics learning helps students develop skills to solve problems in the real world. Problem-solving mentioned by Fitriani, Zubaidah, Susilo and Al Muhdhar (2020) as a method that influences the construction of thought and knowledge.

Problem-solving has become a basic skill that is developed and trained for the needs of students (Franestian, Suyanta \& Wiyono, 2020). According to Docktor and Heller (2009), five indicators affect problem-solving skills in physics including 1) visualization/problem description; 2) physics approach; 3) special application of physics concepts; 4) mathematical procedures; and 5) logical conclusions. Some obstacles determine physics problem-solving skills based on three main things, including students' lack of experience in solving more complex problems, teachers do not facilitate teaching, and students are less able to connect the context of science learning to everyday life (Wati, Sutiniasih, Misbah, Mahtari, Annur \& Mastuang, 2020). What needs to be noted is that problem-based learning is more effective than non-problem-based learning to improve students problem-solving skills (Valdez \& Bungihan, 2019).

\subsection{Online Learning-Digital Learning}

The development of technology and communication has created new opportunities in developing the space for digital learning (Moreno-Morilla, Guzmán-Simón \& García-Jiménez, 2021). Buchanan, Holmes, Preston and Shaw (2015) have found that the increased use of technology causes a transformation of education so that technology is no longer just something that is learned but something with which they learn. In this context, the digital space provides more effective and easier learning experiences and strategies by increasing the control, motivation, and self-satisfaction of students and teachers (Wang, Shannon \& Ross, 2013). In line with this statement, Shaw (2014) emphasized that digital-based learning allows students to accept learning without conventional constraints such as distance and time. Online learning has 4 important objectives, namely 1) easy access; 2) increasing interaction; 3) systematize the learning system; and 4) have the flexibility to reach students in acquiring knowledge (Yacob, Kadir, Zainudin \& Zurairah, 2012). In addition to goals, online learning also directs students to more easily develop self-cognitive and social communication (Lev-On \& Lissitsa, 2018). Even so, Yazdi (2012) 
revealed that in the application of digital-based learning, students are required to take an active (initiative) and exploratory role in finding and understanding their own learning material so that on the one hand online learning provides flexibility. However, on the other hand, it provides difficulties in providing an assessment of the clarity of material in practice (Wanner \& Palmer, 2015; Lock \& Redmond, 2021).

Online learning has become an approach that takes advantage of innovations from internet technology to create and establish an interactive learning environment (Nu'man, 2014). According to Vander-Ark (2012) digital learning will change the world by opening up opportunities and helping students to receive more, faster, deeper, and of course cheaper. However, there are several obstacles in the use of online learning. According to Sari (2012) constraints in the implementation of learning are caused by the mental unpreparedness of the teaching staff in facing digital-based systems, especially when they are used to conventional learning methods. Apart from mental factors, the unpreparedness of tools and access is mentioned by Capogna (2012) as an inhibiting factor for online learning. Limited access and tools due to inadequate funding have led to technological imbalances in some marginalized areas (Capogna, 2012). In line with these arguments, Abidah, Hidaayatullaah, Simamora, Fehabutar and Mutakinati (2020) revealed that inadequate support facilities further aggravate and reduce student competence, thereby limiting student skills and interactions in learning. Somaratne (2016) stated that poor internet facilities become an obstacle for students in exploring material and opening spaces for critical discussion with their groups. The same thing was also expressed by Aditya (2021) who said that the obstacles to the success of digital learning came from the readiness of students, especially those faced by teachers in rural areas. This is what makes online learning a form of inequality for isolated students (Xu \& Jaggars, 2014). On the other hand, online learning results in dependence on technology which then makes students more individualistic (Mathew, 2014).

\section{Method}

The subjects of this study were 50 freshman students of the Department of Physics and Chemistry, Faculty of Science and Technology, UIN Maulana Malik Ibrahim Malang, who were conducting online lectures in the Basic Physics subject with the subject of Mechanics. The research subjects were chosen because these students were new students, when they first entered college they were immediately faced with online learning as a result of the COVID-19 pandemic. Most of them did not know the lecturers who taught their subjects directly, even among classmates too. This condition may result in a lack of learning outcomes.

This type of research is quantitative, information about students' Self-Regulated Learning (SRL) is obtained through a survey using a Likert scale questionnaire that contains grading statements of approval from 15 descriptors which were outlined from 5 (five) indicators of Strongly Agree (SS), Agree (S), Doubt (R), Disagree (TS), and Strongly Disagree (STS). The statement in question is a descriptor of the SRL indicator. The indicators of SRL in this study are (1) diagnosing learning needs, (2) choosing learning strategies, (1) monitoring and managing learning, (4) setting learning targets and goals, and (5) evaluating the process and learning outcomes. Beside the data in the form of a questionnaire, student SRL information was also obtained through written interviews.

Data on student Problem-Solving Skills (PSS) is obtained from the assessment of student work results in solving basic physics questions on mechanics material through scoring rubrics from a score of 0 (zero) to 4 (four). A score of 0 (zero) informs that students are not able to make or use the indicator component. A score of 1 (one) student has been able to make or use the indicator component, but there are some errors. A score of 2 (two) students has been able to make or use the indicator component, but incomplete and inaccurate. A score of 3 (three) students was able to make or use the indicator component completely and accurately. A score of 4 (four) students was able to make or use the indicator component very completely and precisely. Five indicators on the Robust Assessment Instrument for Student Problem-solving developed by Docktor and Heller (2009), namely visualization/problem description, physics approach, special application of physics concepts, mathematical procedures, and logical conclusions. 
SRL and PSS data were analyzed using descriptive analysis. Then the hypothesis test was carried out using the Partial Least Square (PLS) analysis technique with the Smart PLS 3.0 program to find out how the effect of SRL on student PSS in online Basic Physics courses. To test the validity and reliability of the evaluation of the reflective measurement model in PLS analysis, four stages are used, namely internal consistency reliability, convergent validity, indicator reliability, and discriminant validity of the new model. The entire steps in this research shown in Figure 1. Research procedure.

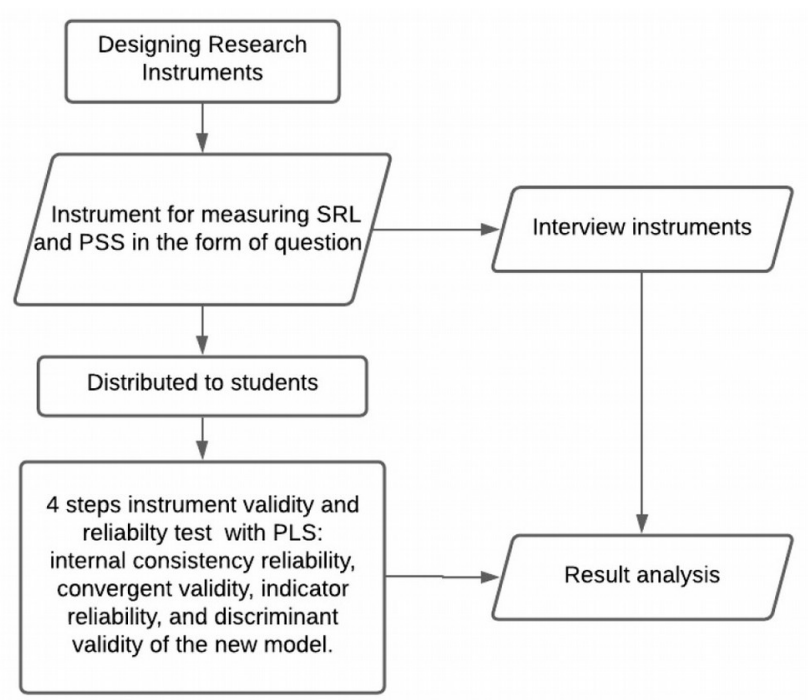

Figure 1. Research procedure

\section{Results}

4.1. Students Self-Regulated Learning (SRL) and Problem-Solving Skill (PSS) During Online Basic Physics Course

\begin{tabular}{|c|c|c|c|c|c|c|}
\hline SRL Indicator & Descriptor & SS & $\mathrm{S}$ & $\mathbf{R}$ & TS & STS \\
\hline \multirow{3}{*}{$\begin{array}{l}\text { Diagnosing } \\
\text { Learning Needs }\end{array}$} & I can identify the conditions that support the learning process & 7 & 32 & 10 & 1 & 0 \\
\hline & $\begin{array}{l}\text { I know when I have to ask a lecturer/friend about material } \\
\text { that I don't understand }\end{array}$ & 9 & 33 & 7 & 0 & 1 \\
\hline & I tried many ways to find out the best method of learning & 20 & 23 & 4 & 2 & 1 \\
\hline \multirow{3}{*}{$\begin{array}{l}\text { Choose a learning } \\
\text { strategy }\end{array}$} & $\begin{array}{l}\text { Apart from taking part in online course, I am looking for } \\
\text { other supporting sources }\end{array}$ & 12 & 32 & 3 & 2 & 1 \\
\hline & $\begin{array}{l}\text { I prefer to have a group discussion to understand more about } \\
\text { the mechanics material }\end{array}$ & 7 & 33 & 8 & 2 & 0 \\
\hline & I know the best way to do my study & 8 & 26 & 14 & 1 & 1 \\
\hline \multirow{3}{*}{$\begin{array}{l}\text { Monitor and } \\
\text { organize learning }\end{array}$} & I arrange my self-study time outside of scheduled online class & 9 & 18 & 13 & 1 & 9 \\
\hline & $\begin{array}{l}\text { The motion mechanics class which was held online made me } \\
\text { more independent in learning }\end{array}$ & 7 & 23 & 15 & 2 & 3 \\
\hline & I mapped the study time according to the course credits & 3 & 25 & 18 & 3 & 1 \\
\hline \multirow{3}{*}{$\begin{array}{l}\text { Setting learning } \\
\text { targets or goals }\end{array}$} & I set a target grade score to be achieved & 10 & 27 & 11 & 0 & 2 \\
\hline & I decided "what to do after learning this" & 10 & 26 & 12 & 0 & 2 \\
\hline & I know my purpose for studying & 17 & 26 & 5 & 1 & 1 \\
\hline \multirow{3}{*}{$\begin{array}{l}\text { Evaluating } \\
\text { learning processes } \\
\text { and outcomes }\end{array}$} & I know what I need to do to optimize online learning & 8 & 34 & 4 & 3 & 1 \\
\hline & Online learning allows me to evaluate learning independently & 5 & 25 & 16 & 2 & 2 \\
\hline & $\begin{array}{l}\text { I try to find my mistakes in studying and plan for } \\
\text { improvement }\end{array}$ & 7 & 34 & 7 & 1 & 1 \\
\hline
\end{tabular}

Table 1. Results of Student SRL Questionnaire Answers on Online Basic Physics Course 
The results of the answers to the questionnaires that have been given to 50 students who are taking online course on Basic Physics with Mechanics material are shown in Table 1. Results of Student SRL Questionnaire Answers on Online Basic Physics Course. The column in the table contains the SRL indicator, a statement of approval in the form of a description, and a gradation component of the approval statement consisting of five options, namely Strongly Agree (SS), Agree (S), Doubt (R), Disagree (TS), and Strongly Disagree (STS).

Interviews were also conducted to evaluate and obtain information on students' SRL. Several obstacles were stated by students in the online physics learning process, including limited internet and network access as conveyed by Informants (1) that "Forced to buy a cellular data package even though financial constraints, or ask for help from other people through sharing the internet connection" (interview, 2020). Whereas all learning activities during the pandemic are demanded to be delivered online, starting from textbooks to materials, causing problems in learning. This was revealed by the Informant (2) that "Delivering material virtually such as slides, PDF document, and video through the WhatsApp group, Telegram, Zoom meeting, and for assignments collected through e-learning that has been provided by the campus" (interview, 2020). The time management to study from home is also a problem for students, because they have the consequence to help their parents while they are studying. It is different if they live in a dormitory or boarding house near campus, students can focus on following lectures. This was conveyed by the Informant (3) that "I have to manage my time between helping my parents and studying, including doing other family tasks, so I need to get used to and force myself to attend class on schedule" (interview, 2020).

\subsection{Student Problem-Solving Skill (PSS)}

Students' answers to the task of solving Basic Physics questions with the Mechanics material given by the lecturer will show information about PSS. Figure 2. Examples of PSS test questions on mechanics material and Figure 3. Examples of student answers are examples of questions and answers from one student in solving these problems.

Meanwhile, an example of one student's answer to the question given is that the student has been able to visualize the story problem in the form of a complete picture sketch with force lines that work on the beam system on an inclined plane. Students write down the physics approach used in solving problems, apply specifically the concept of physics of motion of objects on an inclined plane, use mathematical procedures, and make logical conclusions.

Working Instructions: Do the following questions and upload your answers on Google Drive for Basic Physics course 1. (note: time allocation is 15 minutes)

Ahmad conducted an experiment by placing a beam with a mass of $6 \mathrm{~kg}$ on a smooth board. The beam slide downward on a smooth slope of $30^{\circ}, 45^{\circ}$, and $60^{\circ}$ from the floor. If the distance from the floor to the beam is $10 \mathrm{~m}$ and the gravity acceleration is $10 \mathrm{~ms}^{2}$, then:

a) Write down what is known and sketch an experiment to do!

b) Mention and explain what physics concepts are used to solve these problems!

c) What equations should be used to find the acceleration and time of the block to reach the floor? Explain each symbol in the equation!

d) Determine the acceleration and time required for the block to reach the floor for each angle of inclination!

e) What conclusions did you get from the experiment? What should Ahmad do so that the object's acceleration gets bigger and the travel time is shorter?

Figure 2. Examples of PSS test questions on mechanics material 


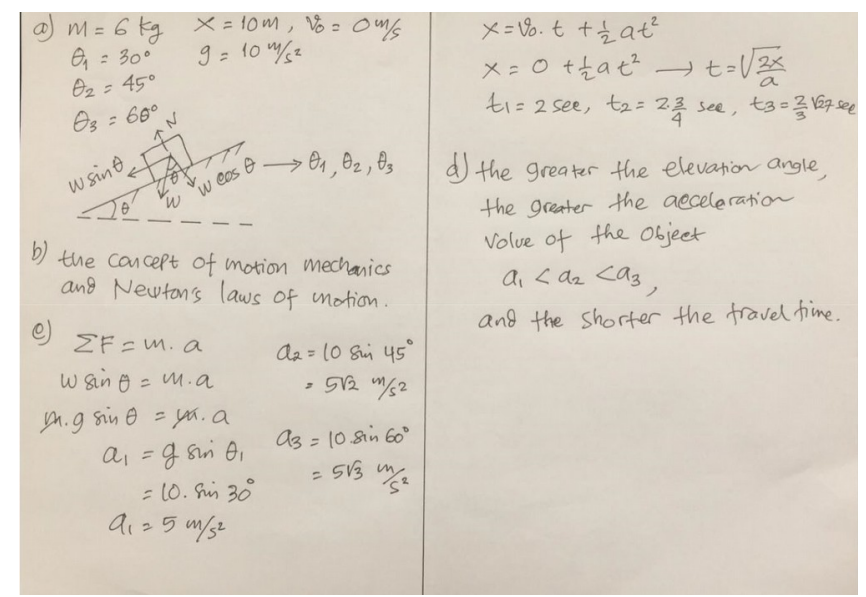

Figure 3. Examples of student answers

The results of the assessment of the student's PSS achievement on each indicator, as well as the scores ranging from 0 (zero) to 4 (four) are shown in Figure 4. Assessment of student problem-solving skills (PSS) on each indicator. The results of the student PSS assessment on each indicator showed that the majority of students got a score of 3 (three) on three indicators, namely "skills in visualizing physics problems", "mentioning the physics approach to be used in solving problems", and "applying specifically the physics concept". So that students have been able to make or use the components of the three indicators completely and accurately. Meanwhile, on the indicator "applying mathematical procedures in solving problems", and "making logical conclusions", the dominant student gets a score of 4, which means that the student has been able to make or use the indicator component very completely and accurately. From the achievement of the five PSS indicators that are the highest or mastered by students are indicators of making logical conclusions.

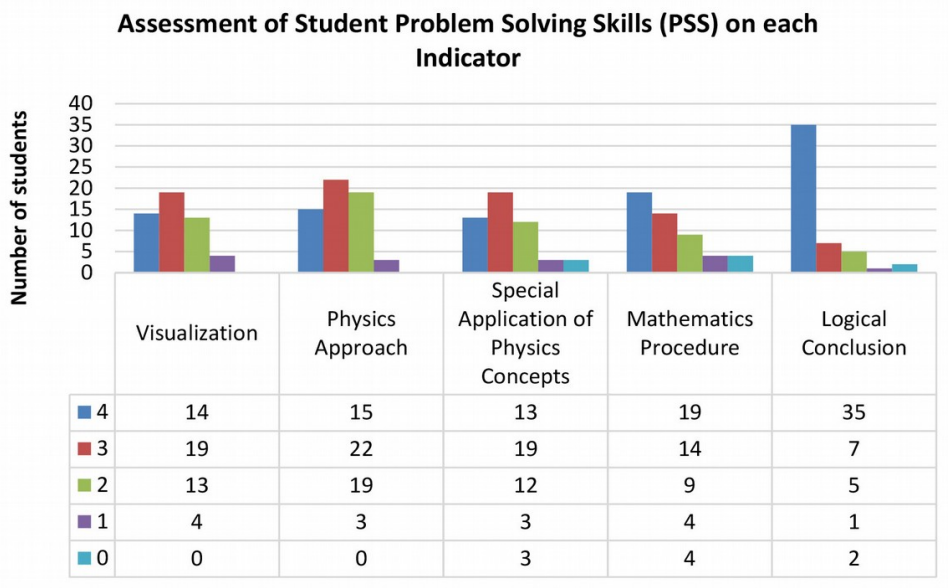

Figure 4. Assessment of student problem-solving skills (PSS) on each indicator

\subsection{Student Self-Regulated Learning (SRL) and Problem-Solving Skill (PSS)}

Based on the research results, there is no effect between Self-Regulated Learning (SRL) and Student Problem-Solving Skills (PSS) in online Basic Physics lectures. Students with good Self-Regulated Learning (SRL) do not necessarily have high Problem-Solving Skills (PSS), and vice versa. This statement is strengthened by testing the hypothesis using the Partial Least Square (PLS) analysis technique with the SmartPLS 3.0 program, with a model framework as in Figure 5.

The description of the relationship between X1.1 and X1.15 is the coding that informs the descriptor of the 5 indicators in Self-Regulated Learning (SRL), each indicator has 3 descriptors so that the total is 15 descriptors. Y1.1 to Y1.5 are codes that inform 5 indicators of student Problem-Solving Skills (PSS). 
Internal consistency reliability is measured by composite reliability (CR). In order to meet the criteria, the CR value must be greater than 0.7 . As shown in Table 2. Reflective measurement model assessment, the Composite reliability (CR) for SRL and PSS are 0.933 and 0.924, respectively, so that they met the criteria for internal consistency reliability. Convergent validity is measured using Average Variance Extracted (AVE). If the AVE value is $>0.5$ then it meets the convergent validity criteria. Average Variance Extracted (AVE) values for SRL and PSS are 0.452 and 0.737 respectively, so that the Self-Regulated Learning (SRL) variable does not meet the convergent validity criteria.

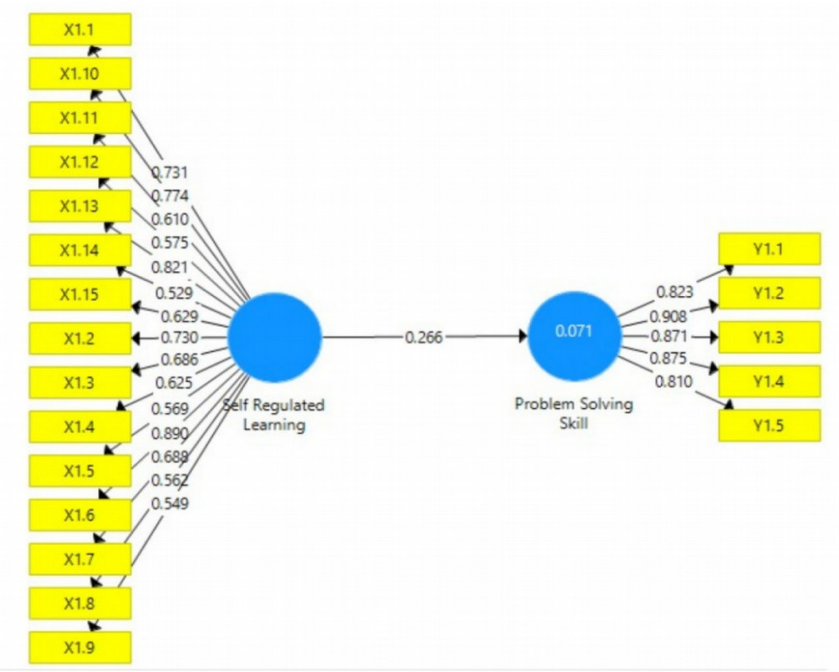

Figure 5. The structural model concept framework

\begin{tabular}{|c|c|c|}
\hline & Problem-Solving Skill & Self-Regulated Learning \\
\hline Composite Reliability & 0.933 & 0.924 \\
\hline Average Variance Extracted (AVE) & 0.737 & 0.452 \\
\hline $\mathrm{X} 1.1$ & & 0.731 \\
\hline $\mathrm{X} 1.10$ & & 0.774 \\
\hline $\mathrm{X} 1.11$ & & 0.610 \\
\hline $\mathrm{X} 1.12$ & & 0.575 \\
\hline $\mathrm{X} 1.13$ & & 0.821 \\
\hline $\mathrm{X} 1.14$ & & 0.529 \\
\hline $\mathrm{X} 1.15$ & & 0.629 \\
\hline $\mathrm{X} 1.2$ & & 0.730 \\
\hline $\mathrm{X} 1.3$ & & 0.686 \\
\hline $\mathrm{X} 1.4$ & & 0.625 \\
\hline $\mathrm{X} 1.5$ & & 0.569 \\
\hline $\mathrm{X} 1.6$ & & 0.890 \\
\hline $\mathrm{X} 1.7$ & & 0.688 \\
\hline $\mathrm{X} 1.8$ & & 0.562 \\
\hline $\mathrm{X} 1.9$ & & 0.549 \\
\hline Y1.1 & 0.823 & \\
\hline Y1.2 & 0.908 & \\
\hline Y1.3 & 0.871 & \\
\hline Y1.4 & 0.875 & \\
\hline Y1.5 & 0.810 & \\
\hline
\end{tabular}

Table 2. Reflective measurement model assessment 
Indicator reliability is measured by analyzing the value of outer loading, if outer loading $>0.7$ then the indicator descriptor is used. Based on Figure 5, there are five SRL indicators. A new structural model is used as shown in Figure 6. New structural model and SEM-PLS analysis results and satisfy composite reliability such as Table 3 . Reflective measurement model assessment for the new model.

\begin{tabular}{|l|c|}
\cline { 2 - 2 } \multicolumn{1}{c|}{} & \multicolumn{2}{c|}{ Composite Reliability } \\
\hline Problem-Solving Skill & 0.931 \\
\hline Self-Regulated Learning & 0.910 \\
\hline
\end{tabular}

Table 3. Reflective measurement model assessment for the new model

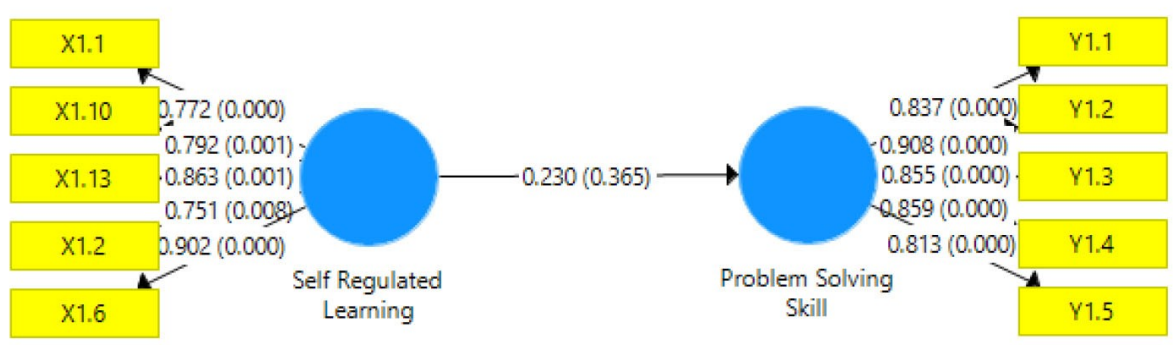

Figure 6. New structural model and SEM-PLS analysis results

Structural model coefficient analysis is used to determine which relationship has a significant effect. The results of the structural model coefficient analysis can be seen in Figure 6. New structural model and SEM-PLS analysis results and Table 4. Coefficients and testing the influence of structural models. If the $\mathrm{p}$-value $<\alpha(0.05)$ then the relationship is significant, otherwise the relationship is not significant.

Based on the result in Table 4. Coefficients and testing the influence of structural models, SRL has no significant effect on PSS in Basic Physics online learning of Mechanics material. Furthermore, to measure the accuracy of the estimates, the coefficient of determination (R2) was assessed. In general, an R2 value of 0.75 is considered to have a large estimation accuracy, an R2 value of 0.50 is considered to have moderate predictive accuracy, and an $\mathrm{R} 2$ value of 0.25 is considered to have weak estimation accuracy. The accuracy of estimating SRL affects PSS in this study is categorized as weak with R2 $=0.053$.

\begin{tabular}{|l|r|r|r|}
\cline { 2 - 4 } \multicolumn{1}{c|}{} & \multicolumn{1}{c|}{ Coefficient } & \multicolumn{1}{c|}{ T Statistics } & \multicolumn{1}{c|}{ P Values } \\
\hline Self-Regulated Learning $\rightarrow$ Problem-Solving Skill & 0.230 & 0.907 & 0.365 \\
\hline
\end{tabular}

Table 4. Coefficients and testing the influence of structural models

\section{Discussion}

SRL has been practiced by students during their online Basic Physics lectures. This paper shows that students diagnose their learning needs on an ongoing basis, starting from conditioning the availability of an internet network and a conducive learning place, organizing study time, using various strategies so that learning objectives are achieved, for example by conducting discussions and completing joint assignments online, and finding learning resources through Internet. This kind of learning is implemented independently to solve some problems in online learning. This will provide more motivation and more learning experiences, learning can be done well and students will be more independent (Putra, Kamil \& Pramudia, 2017). In addition, in SRL students also have a minimum achievement target of learning output and outcomes, as well as evaluating and reflecting on learning processes and outcomes (Azmi, 2016). In the process of completing assignments in the form of answering questions given by lecturers, students have relatively good PSS, they have a tendency to be 
able to describe problems, use concepts, theories, and physical equations, use mathematical procedures to solve problems, and make problems, conclusions completely and precisely. Based on the research data, it turns out that information is obtained that there is no significant effect between SRL on student PSS in online Basic Physics lectures, especially during the ongoing pandemic. While many study findings suggest that the increase in SRL can affect the success of students' studies (Lai \& Gu, 2011; Panadero \& Alonso-Tapia, 2014; Van Eekelen, Boshuizen \& Vermunt, 2005; Veenman, 2015; Winne, 2015). So, it is necessary to find causal factors as part of the evaluation. Thus, an effective online physics learning model can be proposed.

The condition above is a problem that physics educators need to solve. Through various indicators of the causes of constraints of SRL in improving student PSS as shown in the Basic Physics online lectures that have no significant impact. According to Figure 6, the indicators "Choose a learning strategy" with the description "understanding the best approach to learn" and "diagnosing learning needs" with the descriptor "trying various ways to figure out the best technique of learning" are the two most important in building SRL. Inline with Syaf et al. (2017), the most influential sequence of SRL indicators in online learning includes choosing learning strategies, identifying learning needs, and defining learning targets/objectives.

Meanwhile, Figure 6 shows that the "Physical approach" indication, which will be employed in solving the problem according to the given problem, and the "mathematical technique" indicator are the most important PSS indicators. In an aim to increase PSS, these indicators are not generally acknowledged. Several research have looked into visualization indicators in the context of learning physics in order to foster creativity and problem-solving abilities (Manurung \& Panggabean, 2020). As a result of this research, it is necessary to pay close attention so that all PSS and SRL indicators improve, particularly in online learning activities during a pandemic, particularly in Basic Physics lectures. This condition certainly has a lot of influence on the participation of students in learning activities (Abidah et al., 2020).

With the COVID-19 pandemic that is still spreading, online learning cannot be avoided (Daniel, 2020). This condition certainly requires more effective follow-up in delivering online physics learning. This study recommends an importance of online learning that considers conditions, competencies and access to technology as the main support (Chick et al, 2020). This needs to be prepared so that online learning can run optimally, even without the need to meet face to face or offline. With the hope that students' SRL and PSS will increase. In addition, it also requires the establishment of Information and Communication Technologies (ICT) facilities to prepare good learning for students, lecturers, and education providers. Foster consistency in improving SRL and PSS for students through various ways, methods, strategies, and development of certain innovative and practical learning models that can specifically be implemented in online or information-based learning and Communication Technologies (ICT).

\section{Conclusion}

It turns out that SRL, which has been practiced by students in the online physics learning process, has not been optimal in influencing problem-solving skills as a target achievement. This is shown in various activities, namely conditioning various things that support learning activities in the form of preparing for the availability of internet networks during learning, as well as preparing a place to study from home properly, so that learning can run conducive. Always try to get answers if there is information or knowledge that is not yet understood by asking directly to lecturers, having discussions with peers, and looking for learning resource materials using ICT facilities. Students make study time arrangements because of implementing learning from home and have evaluated and reflected on the achievement of their learning outcomes.

The concept of SRL and PSS, as used in this study needs to be evaluated to achieve learning targets. Several things that may be evaluated in solving physics problems include visualizing physics problems, explaining the right physics concepts to solve problems, special applications of physics concepts, 
mathematical applications in solving physics problems, and making logical conclusions completely and accurately have been implemented. From the five indicators, the dominant ones shown by the number of students and high scores are the application of mathematical procedures in solving physics problems and making logical conclusions.

This study is limited to the object of study used which is still relatively small, so it is possible to carry out further studies with a wider object of study. Likewise, the findings of this study state that there is no significant effect between SRL and Student PSS in Basic Physics courses that are conducted online. Until now, Basic Physics learning is considered effective if it is carried out offline, it turns out that it cannot be implemented through online learning. Thus, various efforts are needed so that Basic Physics online learning can run optimally, and learning objectives can be achieved, including student SRL and student PSS. It is necessary to establish the availability and literacy of Information and Communication Technologies (ICT) during the process of preparation, implementation and evaluation of learning for students, lecturers, and education providers. Another most important thing is that students need to develop consistency in SRL and PSS through various ways, methods, strategies, and development of innovative and practical learning models that can specifically be implemented in online learning.

\section{Declaration of Conflicting Interests}

The authors declared no potential conflicts of interest with respect to the research, authorship, and/or publication of this article.

\section{Funding}

The authors received no financial support for the research, authorship, and/or publication of this article.

\section{References}

Abidah, A., Hidaayatullaah, H.N., Simamora, R.M., Fehabutar, D., \& Mutakinati, L. (2020). The Impact of Covid-19 to Indonesian Education and Its Relation to the Philosophy of "Merdeka Belajar". Studies in Philosopby of Science and Education (SiPoSE), 1(1), 38-49. https://doi.org/10.46627/sipose.v1i1.9

Aditya, D.S. (2021). Embarking Digital Learning Due to COVID-19: are Teachers Ready? Journal of Technology and Science Education, 11(1), 104-116. https://doi.org/10.3926/jotse.1109

Almaiah, M.A., Al-Khasawneh, A., \& Althunibat, A. (2020). Exploring the critical challenges and factors influencing the E-learning system usage during COVID-19 pandemic. Education and Information Technologies. https://doi.org/10.1007/s10639-020-10219-y

Anderson, J.R. (1993). Problem solving and learning. American Psychologist. https://doi.org/10.1037/0003-066X.48.1.35

Argaw, A.S., Haile, B.B., Ayalew, B.T., \& Kuma, S.G. (2017). The Effect of Problem Based Learning (PBL) Instruction on Students' Motivation and Problem Solving Skills of Physics. Eurasia Journal of Mathematics, Science and Technology Education, 13(3), 857-871. https://doi.org/10.12973/eurasia.2017.00647a

Azmi, S. (2016). Self Regulated Learning Salah Satu Modal Kesuksesan Belajar dan Mengajar. Jurnal Pedagogi Dan Pembelajaran.

Barzilai, S., \& Blau, I. (2014). Scaffolding game-based learning: Impact on learning achievements, perceived learning, and game experiences. Computers and Education. https://doi.org/10.1016/j.compedu.2013.08.003

Buchanan, R., Holmes, K., Preston, G., \& Shaw, K. (2015). The Global and the Local: Taking Account of Context in the Push for Technologization of Education. In Critical Perspectives on Technology and Education. https://doi.org/10.1057/9781137385451_13 
Capogna, S. (2012). University and e-learning classes in Italy. E-Learning and Digital Media, 9(2), 143-156. https://doi.org/10.2304/elea.2012.9.2.143

Carleo, G., \& Troyer, M. (2017). Solving the quantum many-body problem with artificial neural networks. Science. https://doi.org/10.1126/science.aag2302

Castro-Schez, J.J., Glez-Morcillo, C., Albusac, J., \& Vallejo, D. (2021). An intelligent tutoring system for supporting active learning: A case study on predictive parsing learning. Information Sciences. https://doi.org/10.1016/j.ins.2020.08.079

Chick, R.C., Clifton, G.T., Peace, K.M., Propper, B.W., Hale, D.F., Alseidi, A.A. et al. (2020). Using Technology to Maintain the Education of Residents During the COVID-19 Pandemic. Journal of Surgical Education. https://doi.org/10.1016/j.jsurg.2020.03.018

Chua, B.L., Tan, O.S., \& Liu, W.C. (2016). Journey into the problem-solving process: cognitive functions in a PBL environment. Innovations in Education and Teaching International.

https:// doi.org/10.1080/14703297.2014.961502

Clark, I. (2012). Formative Assessment: Assessment Is for Self-regulated Learning. In Educational Psychology Review. https://doi.org/10.1007/s10648-011-9191-6

Daniel, S.J. (2020). Education and the COVID-19 pandemic. Prospects. https://doi.org/10.1007/s11125-020-09464-3

De Cock, M. (2012). Representation use and strategy choice in physics problem solving. Physical Review Special Topics - Physics Education Research. https://doi.org/10.1103/PhysRevSTPER.8.020117

Docktor, J., \& Heller, K. (2009). Robust assessment instrument for student problem solving. Proceedings of the NARST 2009 Annual Meeting. https://doi.org/10.1063/1.3266696

English, M.C., \& Kitsantas, A. (2013). Supporting Student Self-Regulated Learning in Problem- and Project-Based Learning. Interdisciplinary Journal of Problem-Based Learning. https://doi.org/10.7771/1541-5015.1339

Fitriani, A., Zubaidah, S., Susilo, H., \& Al Muhdhar, M.H.I. (2020). The Effects of Integrated Problem-Based Learning, Predict, Observe, Explain on Problem-Solving Skills and Self-Efficacy. Eurasian Journal of Educational Research, 85, 45-64. https://doi.org/10.14689/ejer.2020.85.3

Franestian, I.D., Suyanta, \& Wiyono, A. (2020). Analysis problem solving skills of student in Junior High School. Journal of Physics: Conference Series, 1440(1). https://doi.org/10.1088/1742-6596/1440/1/012089

Hadwin, A.F., Järvelä, S., \& Miller, M. (2015). Self-Regulated, Co-Regulated, and Socially Shared Regulation of Learning. In Handbook of Self-Regulation of Learning and Performance. https://doi.org/10.4324/9780203839010.ch5

Han, H.X.D., \& Toh, T.L. (2019). Use of animation to facilitate students in acquiring problemsolving: From Theory to Practice. Mathematics Enthusiast.

Hu, Y., Wu, B., \& Gu, X. (2017). Learning analysis of K-12 students' online problem solving: a threestage assessment approach. Interactive Learning Environments, 4820(March), 262-279. https://doi.org/10.1080/10494820.2016.1276080

Jacobse, A.E., \& Harskamp, E.G. (2012). Towards efficient measurement of metacognition in mathematical problem solving. Metacognition and Learning. https://doi.org/10.1007/s11409-012-9088-x

Karatas, I., \& Baki, A. (2013). The effect of learning environments based on problem solving on students' achievements of problem solving. International Electronic Journal of Elementary Education. 
Kim, M.C., \& Hannafin, M.J. (2011). Scaffolding problem solving in technology-enhanced learning environments (TELEs): Bridging research and theory with practice. Computers and Education. https://doi.org/10.1016/j.compedu.2010.08.024

Kozhevnikov, M., Motes, M.A., \& Hegarty, M. (2007). Spatial visualization in physics problem solving. Cognitive Science. https://doi.org/10.1080/15326900701399897

Krawec, J.L. (2014). Problem Representation and Mathematical Problem Solving of Students of Varying Math Ability. Journal of Learning Disabilities. https://doi.org/10.1177/0022219412436976

Kuiper-Anne, R., \& Pesut, J.D. (2016). Promoting cognitive and metacognitive reflective reasoning skills in nursing practice: self regulated learning theory. Journal of Advance Nursing.

Lai, C., \& Gu, M. (2011). Self-regulated out-of-class language learning with technology. Computer Assisted Language Learning. https://doi.org/10.1080/09588221.2011.568417

Landau, R.H., Páez-Mejía, M.J., \& Bordeianu, C.C. (2015). Computational physics: problem solving with Python (3rd Completely Revised Edition).

Laurens, T., Batlolona, F.A., Batlolona, J.R., \& Leasa, M. (2018). How Does Realistic Mathematics Education (RME) Improve Students' Mathematics Cognitive Achievement? Eurasia Journal of Mathematics, Science and Technology Education, 14(2), 569-578. https://doi.org/10.12973/ejmste/76959

Learning, D.G. (2001). Fun, Play and Games: What Makes Games Engaging. Scientist.

Lev-On, A., \& Lissitsa, S. (2018). Facilitating cross-cleavage communication online: Findings from interviews with ultra-Orthodox, religious, and secular participants. Communication Review. https://doi.org/10.1080/10714421.2018.1495434

Lock, J., \& Redmond, P. (2021). Embedded experts in online collaborative learning: A case study. Internet and Higher Education. https://doi.org/10.1016/j.iheduc.2020.100773

Manurung, S.R., \& Panggabean, D.D. (2020). Improving students' thinking ability in physics using interactive multimedia based problem solving. Cakrawala Pendidikan.

https://doi.org/10.21831/cp.v39i2.28205

Mathew, D. (2014). E-learning, time and unconscious thinking. E-Learning and Digital Media, 11(2), 135-140. https://doi.org/10.2304/elea.2014.11.2.135

Mestre, J.P., Docktor, J.L., Strand, N.E., \& Ross, B.H. (2011). Conceptual Problem Solving in Physics. In Psychology of Learning and Motivation - Advances in Research and Theory.

https://doi.org/10.1016/B978-0-12-387691-1.00009-0

Moreno-Morilla, C., Guzmán-Simón, F., \& García-Jiménez, E. (2021). Digital and information literacy inside and outside Spanish primary education schools. Learning, Culture and Social Interaction. https://doi.org/10.1016/j.lcsi.2020.100455

Norman, G.R. (1988). Problem-solving skills, solving problems and problem-based learning. Medical Education. https://doi.org/10.1111/j.1365-2923.1988.tb00754.x

Nu'man, A.Z. (2014). Efektifitas Penerapan E-Learning Model Edmodo Dalam Pembelajaran Pendidikan Agama Islam Terhadap Hasil Belajar Siswa (Studi Kasus: SMK Muhammadiyah 1 Sukoharjo). Duta.Com ISSN, 7(1).

Panadero, E., \& Alonso-Tapia, J. (2014). How do students self-regulate? Review of Zimmerman's cyclical model of self-regulated learning. Anales de Psicologia / Annals of Psychology.

https://doi.org/10.6018/analesps.30.2.167221 
Putra, R.A., Kamil, M., \& Pramudia, J.R. (2017). Penerapan Metode Pembelajaran Mandiri Dalam Meningkatan Hasil Belajar Peserta Didik. Jurnal Pendidikan Luar Sekolah.

Retnowati, E., Fathoni, Y., \& Chen, O. (2018). Mathematics problem solving skill acquisition: Learning by problem posing or by problem solving. Cakrawala Pendidikan. https://doi.org/10.21831/cp.v37i1.18787

Rodzalan, S.A., \& Saat, M.M. (2015). The Perception of Critical Thinking and Problem Solving Skill among Malaysian Undergraduate Students. Procedia - Social and Behavioral Sciences. https://doi.org/10.1016/j.sbspro.2015.01.425

Sánchez, J., \& Olivares, R. (2011). Problem solving and collaboration using mobile serious games. Computers and Education. https://doi.org/10.1016/j.compedu.2011.04.012

Sari, E.R. (2012). Online learning community: A case study of teacher professional development in Indonesia. Intercultural Education, 23(1), 63-72. https://doi.org/10.1080/14675986.2012.664755

Schoenfeld, A.H. (2016). Learning to Think Mathematically: Problem Solving, Metacognition, and Sense Making in Mathematics. Journal of Education. https://doi.org/10.1177/002205741619600202

Schunk, D.H., \& Zimmerman, B.J. (2012). Motivation and self-regulated learning: Theory, research, and applications. In Motivation and Self-Regulated Learning: Theory, Research, and Applications. https://doi.org/10.4324/9780203831076

Shaw, R. (2014). Heidegger and e-learning: Overthrowing the traditions of pedagogy. E-Learning and Digital Media, 11(2), 123-134. https://doi.org/10.2304/elea.2014.11.2.123

Singh, C. (2009). Problem solving and learning. AIP Conference Proceedings. https://doi.org/10.1063/1.3183522

Snyder, L.G., \& Snyder, M.J. (2008). Teaching critical thinking and problem solving skills. The Delta Pi Epsilon Journal.

Somaratne, R.M.P.N. (2016). Exploring the user experiences of collaborative online learning. $15^{\text {th }}$ International Conference on Advances in ICT for Emerging Regions, ICTer 2015 - Conference Proceedings. https://doi.org/10.1109/ICTER.2015.7377701

Sukariasih, L., Tahang, L., Nursalam, L.O., \& Fayanto, S. (2020). Description of physics problem-solving in the topic of static fluid: Case study of physics education in Halu Oleo University. Universal Journal of Educational Research. https://doi.org/10.13189/ujer.2020.081025

Sweller, J. (1988). Cognitive load during problem solving: Effects on learning. Cognitive Science. https://doi.org/10.1016/0364-0213(88)90023-7

Syaf, A., Kuryadinata, H., \& Widiasty, T. (2017). Self Regulated Learning Mahasiswa pada Implementasi Pembelajaran daring Mata Kuliah Kalkulus Vektor. Jurnal Ilmiah Pendidikan Matematika.

Tambychik, T., \& Meerah, T.S.M. (2010). Students' difficulties in mathematics problem-solving: What do they say? Procedia - Social and Behavioral Sciences. https://doi.org/10.1016/j.sbspro.2010.12.020

Valdez, J.E., \& Bungihan, M.E. (2019). Problem-based learning approach enhances the problem solving skills in chemistry of high school students. Journal of Technology and Science Education, 9(3), 282-294. https://doi.org/10.3926/JOTSE.631

Van Eekelen, I.M., Boshuizen, H.P.A., \& Vermunt, J.D. (2005). Self-regulation in higher education teacher learning. Higher Education. https://doi.org/10.1007/s10734-004-6362-0

Van Merriënboer, J.J.G. (2013). Perspectives on problem solving and instruction. Computers and Education. https://doi.org/10.1016/j.compedu.2012.11.025 
Vander-Ark, T. (2012). Getting smart: How digital learning is changing the world. In Getting Smart: How Digital Learning is Changing the World.

Veenman, M.V.J. (2015). Learning to Self-Monitor and Self-Regulate. In Handbook of Research on Learning and Instruction. https://doi.org/10.4324/9780203839089.ch10

Walsh, L.N., Howard, R.G., \& Bowe, B. (2007). Phenomenographic study of students' problem solving approaches in physics. Physical Review Special Topics - Physics Education Research. https://doi.org/10.1103/PhysRevSTPER.3.020108

Wang, C.H., Shannon, D.M., \& Ross, M.E. (2013). Students' characteristics, self-regulated learning, technology self-efficacy, and course outcomes in online learning. Distance Education, 34(3), 302-323. https://doi.org/10.1080/01587919.2013.835779

Wanner, T., \& Palmer, E. (2015). Personalising learning: Exploring student and teacher perceptions about flexible learning and assessment in a flipped university course. Computers and Education. https://doi.org/10.1016/j.compedu.2015.07.008

Wati, M., Sutiniasih, N., Misbah, Mahtari, S., Annur, S., \& Mastuang (2020). Developing of physics teaching materials based on authentic learning to train problem-solving skills. Journal of Physics: Conference Series. https://doi.org/10.1088/1742-6596/1567/3/032084

Winne, P.H. (2010). Improving measurements of self-regulated learning. Educational Psychologist. https://doi.org/10.1080/00461520.2010.517150

Winne, P.H. (2015). Self-Regulated Learning. In International Encyclopedia of the Social \& Behavioral Sciences (Second Edition). https://doi.org/10.1016/B978-0-08-097086-8.25091-5

Wong, J., Baars, M., de Koning, B.B., \& Paas, F. (2021). Examining the use of prompts to facilitate self-regulated learning in Massive Open Online Courses. Computers in Human Behavior. https://doi.org/10.1016/j.chb.2020.106596

Xu, D., \& Jaggars, S.S. (2014). Performance gaps between online and face-to-face courses: Differences across types of students and academic subject areas. Journal of Higher Education.

https://doi.org/10.1353/jhe.2014.0028

Yacob, A., Kadir, A.Z.A., Zainudin, O., \& Zurairah, A. (2012). Student Awareness Towards E-Learning In Education. Procedia - Social and Behavioral Sciences, 67(November 2011), 93-101.

https://doi.org/10.1016/j.sbspro.2012.11.310

Yazdi, M. (2012). E-learning sebagai Media Pembelajaran Interaktif Berbasis teknologi Informasi. Jurnal Ilmua Foristek.

Zheng, J., Huang, L., Li, S., Lajoie, S.P., Chen, Y., \& Hmelo-Silver, C.E. (2020). Self-regulation and Emotion Matter: A Case Study of Instructor Interactions with a Learning Analytics Dashboard. Computers \& Education. https:// doi.org/10.1016/j.compedu.2020.104061

Published by OmniaScience (www.omniascience.com) Journal of Technology and Science Education, 2021 (www.jotse.org)

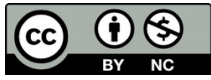

Article's contents are provided on an Attribution-Non Commercial 4.0 Creative commons International License. Readers are allowed to copy, distribute and communicate article's contents, provided the author's and JOTSE journal's names are included. It must not be used for commercial purposes. To see the complete licence contents, please visit https://creativecommons.org/licenses/by-nc/4.0/. 